\title{
SOME SUBACUTE HISTOPATHOLOGICAL EFFECTS OF \\ CARBOSULFAN TECHNICAL AND MARSAL 20\% EC FORMULATION IN MALE ALBINO RATS
}

MAGED M. RIZK ALLA

\author{
Central Agricultural Pesticides Lab., ARC, Dokki, Giza
}

(Manuscript received 19 September 2010)

\begin{abstract}
Six equal groups of adult male albino rats were orally administered with three different concentrations $(14,7,3.5 \mathrm{mg} / \mathrm{kg}$ bw.) of carbosulfan technical (88.5\%) and Marsal $20 \%$ EC Formulation (one conc. of each form per group) for 28 consecutive days, then kept two other weeks without treatment as a recovery period.

Samples of brain, thyroid, lung and spleen tissues were taken from all groups at the end of treatment and recovery periods, examined microscopally and compared with control tissues.

Results showed that the treatment with technical carbosulfan not affected on thyroid tissues, when affected on brain, lung and spleen tissues, then lung and spleen tissues were repaired after the recovery period but brain tissues still damaged.

In case of Marsal $20 \% \mathrm{EC}$ formulation treatment both thyroid and brain tissues not affected, when both lung and spleen tissues affected and this effect was repaired after the recovery period and the tissues returned to normal state.
\end{abstract}

\section{INTRODUCTION}

Carbosulfan insecticide is widely used in agriculture to control a wide rang of soil-dwelling and foliar insect pests on several crops, recently it was proposed for treatment against pyrethroid-resistant mosquitoes (Guillet et al 2001). Carbosulfan mammalian toxicology was studied by many investigators as ksheerasogar and Kaliwal (2006) who studied the histopathological and biochemical changes in the liver of albino mice treated with carbosulfan, the effect on rat stomach was studied by Noriharu and Fukuto (1982), Raghavendra and Kaliwal (2008) investigated its effect on estrous cycle and follicular dynamics in albino mice, its acute toxicity in the rat after intravenous and oral exposures was studied by Barbara and Krieger (1986), the chromosomal aberrations in bone marrow cells of rats treated with carbosulfan was investigated by Mehmet et al (1996) and in mice by Sarbani et al (2002).

The present study aimed to clarify the subacute histopathological effects of three different doses of two carbosulfan forms (technical $88.5 \%$ and commercial compound Marsal. $20 \%$ EC) on some organs tissues of male albino rats at the end of treatment and after two weeks recovery periods. 


\section{MATERIALS AND METHODS}

Chemical: Carbosulfan an anticholinesterase methyl carbamate currently in local use as a soil and foliar insecticide, its chemical name is 2, 3-dihydro-2, 2-dimethyl-7benzofuranyl [(di-n-butylamino)thio]-methl carbamate. Its human initial signs of toxicity include sweating, nausea and blurred vision (Gosselin et al, 1984). Its technical $88.5 \%$ and EC. $20 \%$ formulation (marsal) were obtained from Delta Agrochemicals Co. and used in this study.

Experimental animals: Adult male albino rats (Wister strain) weighting 170-190 g. were used in this study. Animals were acclimatized for two weeks prior to study under normal healthy laboratory conditions in the animal house of the Mammalian Toxicology Department, Central Agricultural Pesticides Laboratory, and were fed a normal commercial diet and allowed free excess of water.

Subacute experimental design: For each form of the tested pesticide 35 animals were randomly divided into 7 groups of equal five rats each. The groups were treated as follows:

Groups 1, 2: The animals were administrated the dose of $14 \mathrm{mg}$ a.i. $/ \mathrm{kg} \mathrm{bw}$. of the carbosulfan form (technical or formulation) as a high dose.

Groups 3, 4: The animals were administrated the dose of $7 \mathrm{mg} \mathrm{a.i.} / \mathrm{kg} \mathrm{bw}$. of the carbosulfan form (technical or formulation) as a medium dose.

Groups 5, 6: The animals were administrated the dose of $3.5 \mathrm{mg}$ a.i. $/ \mathrm{kg} \mathrm{bw}$. of the carbosulfan form (technical or formulation) as a low dose.

Group 7: The animals were received distilled water to be used as control.

The rats were treated orally by metallic stomach tube for 28 consecutive days and, kept without treatment for 14 days as a recovery period.

Histopathological examination: At the end of treatment and recovery periods brain, lung, thyroid and spleen tissues specimens were taken in $10 \%$ formalin solution from all groups of treated animals during the post-mortem examination and were fixed in $10 \%$ formal saline. The fixed tissues were washed in tap water, dehydrated in a series of alcohol, cleared in xylene then embedded in paraffin. Five microns paraffin sections were obtained and stained with Hematoxylin and Eosin stain as mentioned by Carleton et al. (1967) for histopathological examination.

\section{RESULTS AND DISCUSSION}

The increased mammalian safety of the sulfenylated derivatives of toxic methylcarbamate esters (like carbosulfan) has been attributed to the delay factor provide by the $\mathrm{N}$ - sulfenyl moiety; i.e., derivatization allows the compound to be 
metabolized to nontoxic products before intoxication can take place (Fahmy and Fukuto, 1981).

Maged et al., (2006) were reported that the two carbosulfan used forms caused several subacute histological damages in liver and kidney tissues, where the damages were more occurred by the technical than the formulation. The present study was considered the effect of three different doses $(14,7,3.5 \mathrm{mg} / \mathrm{kg}$ bw. a. i.)of both technical $88.5 \%$ and $20 \%$ EC. Carbosulfan on brain, thyroid, lung and spleen rat tissues after four weeks daily oral exposure and two weeks later as recovery period.

De Prospo et al (1982) were reported malignant lymphoma, bronchio-alveolar adenoma and significant increase in the number of metastatic malignant lymphomas of mediastinal and mesenteric lymph nodes, as well as thymus and spleen in control and low-dose treated mices, so these results and incidence of non-neoplastic and neoplastic lesions considered usual and unrelated to Carbosulfan treatment.

The examination of brain tissues showed infiltration oedema around congested blood vessels and some neurons by all doses of the technical carbosulfan which stilled after the recovery period, where no changes were noticed by the formulation doses.

No effect was noticed by the two tested forms of carbosulfan on thyroid tissues at all used doses.

In case of lung tissues examination, the two tested carbosulfan forms produced a simple bronchopneumonia by all doses, which was disappeared after the recovery period.

Also the treatment of technical or $20 \%$ EC formulation of carbosulfan was produced a decrease in the number of lymphocytes in spleen white follicles by all used doses and this decrease returned to normal after the recovery period.

The not recovered brain tissues damage by the technical carbosulfan was suspected, where brain is the main target organ to carbamates which many pervious investigations proved their neurotoxicity (Chantal et al., 2003, Miller 1982). 
SOME SUBACUTE HISTOPATHOLOGICAL EFFECTS OF CARBOSULFAN

TECHNICAL AND MARSAL 20\% EC FORMULATION IN MALE ALBINO RATS 


\section{REFERENCES}

1- Barbara, E.R. and R.I. Krieger. 1986. Sublethal acute toxicity of carbosulfan [2, 3dihydro-2, 2-dimethyl-7-benzofuranyl (di-n-butylaminosulfenyl) (methyl) carbamate] in the rat after intravenous and oral exposure, Fundamental and Applied Toxicology, V.6 N.1, pp.7-15.

2- Carleton, H.M., R.A.B. Druy and E.A. Willington. 1967. Carleton's Histological Technique 4th Ed. Oxford Univ. Press, N.Y.

3- Chantal, J.G.M.S., T.J.H. Bueters, R.G.D.M. Van Kleef and H.P.M. vijverberg. 2003. Selective effects of carbamate pesticides on rat neuronal nicotinic acetylcholine receptors and rat brain acetylcholinesterase, Toxicology and Applied Pharmacology, 193, pp. 139-146.

4- DeProspo, J.R., M.J. Norvell and M.J. Flectcher. 1982. Twenty-four month dietary toxicity/oncogenicity study in mice with FMC 35001. FMC Report No. A79-334. FMC Corporate Toxicology Department. Submitted by FMC Corp. to WHO.

5- Fahmy, M.A. and T.R. Fukuto. 1981. N-sulfinylated derivatives of methylcarbamate esters, J. Agric. Food Chem., V.29 (3), pp. 567-572.

6- Gosselin, R.E., R.P. Smith and H.C. Hodge.1984. Clinical toxicology of commercial products 5th Ed., Baltimore, Williams and Wilkins, p. 305.

7- Guillet, P., R. N'Guessan, F. Darriet, M. Traore-Lamizana, F. Chanre, and P. Carnevale. 2001. Combined pyrethroid and carbamate 'two-in-one' treated mosquito nets: field efficacy against pyrerthroid-resistant Anopheles gambiae and Culex quinquefasciatus. Med. Vet. Entomol., 15, 102-112.

8- Ksheerasogar, R.L. and B.B. Kaliwal. 2006. Histological and biochemical changes in the liver of Albino Mice on exposure to insecticide, carbosulfan, Caspian J. Environ. Sci, V.4, N.31, pp. 67-70.

9- Maged, M.R., M.M. Talha and K.A. Ibrahim. 2006. Some subacute liver and kidney damages induced by carbosulfan in male albino rats, J. Biol. Chem. Environ. Sci. V.1 (2) pp. 275-288.

10- Mehmet, T., E. R. Ullari and H.B. La. 1996. In vivo chromosomal aberrations in bone marrow cells of rats treated with Marshal, Mutation Research/ Genetic Toxicology, V.371, N.3-4, pp. 259-264.

11- Miller, D.B. 1982. Neurotoxicity of the pesticidal carbamates, Neurobehav. Toxicol. V. 4(6), pp. 779-787.

12- Noriharu, V. and R. Fukuto. 1982. Alteration of carbosulfan [2, 3-dihydro-2,2dimethyl-7-benzofuranyl(Di-n-butylaminosulfenyl)methylcarbamate] in the rat stomach, J. Agric. Food Chem., v. 30, pp. 555-557. 
13- Raghavendra, L.K. and B.B. Kaliwal. 2008. Effect of carbosulfan administration schedules on estrous cycle and follicular dynamics in albino mice, Industrial Health, V. 46, N. 3, pp. 201-216.

14- Sarbani, G., A. Giri, G.D. Sharma and S.B. Prasod. 2002. Mutagenic effects of carbosulfan, a carbamate pesticide, Mutation Research / Genetic Toxicology and Environmental Mutagenesis, V. 519, N. 1-2, pp. 75-82. 
بعض التأثيرات الهيستوباثولوجية تحث الحادة لخام الكربوسلفان ومستحضر 20\% منه مركز قابل للاستحلاب(مارسار) فى ذكور الفئر ان البيضاء

ماجد منصور رزق الله

قسم بحوث سمبة المبيد/ت للثدبيات و الأحياء المائية-الدعل المركزى للمبيد/ت- مركز البحوث

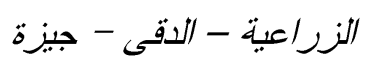

عوملت 6 مجموعات منساوية العدد من ذكور الفئران البيضاء البالغة عن طريق التجريع

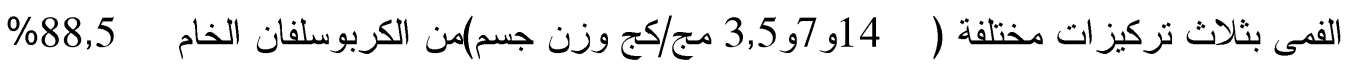

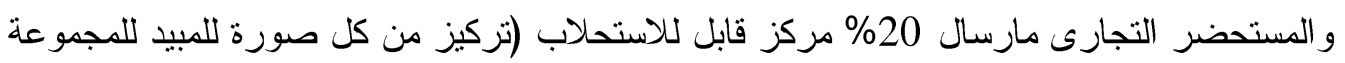
الو احدة) لمدة 28 يوم متو اصلة وتركت أسبو عين أخرين دون معاملة كفترة أستشفاء ثم أخذت عبن عينات من أنسجة المخ و الغدة الدرقية و الرئة و الطحال من كل المجموعات فيى نهاية فترة المعاملة وفى نهاية فترة الأستشفاء وفحصت ميكروسكوبيا وقورنت بمجموعة الكنترول ـ وقد أظهرت النتائج أن المعاملة بالمادة الخام للكربوسلفان لم تؤثر على أنسجة الغدة الدرقية بينما أثرت على كلا ونلا من أنسجة الرئة

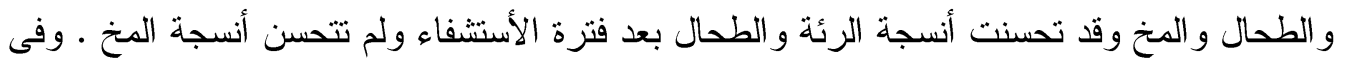

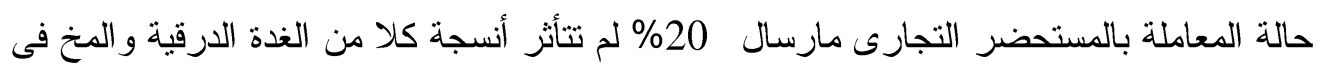
حين تأثرت أنسجة كلا من الرئة و الطحال وتلاشىى هذا التأثير تقريبا واستعادت الأنسجة الحالة الطبيعية بعد فترة الأستشفاء . 